\title{
A Round-Robin Test with Thermal Simulation of the Welding HAZ to draw CCT diagrams: a need for harmonized procedures and microconstituent terminologies
}

(Um Round-Robin Teste com Simulação Térmica da ZAC de Soldagem para Obtenção de Diagramas CRC: a necessidade de procedimentos e terminologia de microconstituintes harmonizados)

\author{
Américo Scotti ${ }^{1}$, Huijun Lit, Rosa M. Miranda ${ }^{3}$ \\ ${ }^{1}$ Federal University of Uberlandia, Uberlândia, MG, Brazil, ascotti@ufu.br \\ ${ }^{2}$ University of Wollongong,Wollongong, Australia, huijun@uow.edu.au \\ ${ }^{3}$ University Nova de Lisboa, Lisbon, Portugal,rmmdm@fct.unl.pt
}

\begin{abstract}
Thermal simulations of heat affected zone (HAZ) have been widely used. This is an economic expedite process for phase transformation evaluations in steels when subjected to weld thermal cycles as well as to draw continuous cooling transformation (CCT) diagrams. Different approaches for the simulation and parameter settings have been used by several researchers, yet leading to not always even results. Thus, it was proposed a round-robin test trial performed by different laboratories, aiming to evidence potential sources of error or inadequacy of the approaches. A High Strength Low Alloy (HSLA) steel was used as a case study. Despite the limited number of tests, the results show low robustness when comparing the outcomes from the different laboratories and point out for the need to take three actions. The first one is to implement a cooperative and multi-institutional program to assess the effect of relevant simulation parameters, such as the heating rate and holding time at peak temperature, on the final microstructure and transformation temperatures as well as on the hardness for a given cooling rate. The second is to propose calibration procedures for the simulation and measurement systems. The third action is to stimulate experts in this area to develop a guideline of terminology for constituents in the heat affected zone of ferritic steels.
\end{abstract}

Keywords: round-robin test; thermal simulation; CCT diagram; HSLA steels

Resumo: Simulações térmicas de zona afetada de calor (ZAC) têm sido amplamente utilizadas. Este é um meio econômico e agil para avaliação das transformações de fase em aços quando submetidos a ciclos térmicos de soldagem, bem como para determinar diagramas de transformação de resfriamento contínuo $(C R C)$. Diferentes abordagens para a simulação e configuração de parâmetros têm sido usadas por vários pesquisadores, embora conduzindo a resultados não totalmente similares. Assim, foi proposta uma rodada do tipo "round-robin" teste com diferentes laboratórios, com o objetivo de evidenciar potenciais fontes de erro ou inadequação das abordagens. Um aço alta resistência baixa liga (ARBL) foi usado como estudo de caso. Apesar do número limitado de testes, os dados mostram baixa robustez quando comparados os resultados advindos dos diferentes laboratórios e apontam para a necessidade de se programar três ações. A primeira é para implementar um programa cooperativo e multi-institucional para avaliar o efeito dos parâmetros relevantes da simulação, tais como a taxa de aquecimento e tempo de permanência na temperatura de pico, sobre as microestrutura e temperaturas finais de transformação, bem como sobre a dureza, de uma dada taxa de resfriamento. A segunda é propor procedimentos de calibração para os sistemas de simulação e medição. A terceira ação é estimular os especialistas desta área para desenvolver um guia de terminologia para constituintes na zona afetadapelo calor de aços ferríticos.

Palavras chave: round-robin teste; simulação térmica; Digrama CRC; aços ARBL

\section{Introduction}

A generation of structural steels, such as microalloyed and high strength low alloy (HSLA) steels, surged in recent years with impressive combination of properties (high yield strength

Recebido em 02/09/2014, texto final em 02/09/2014.

DOI: http://dx.doi.org/10.1590/0104-9224/SI1903.11 and toughness), due to their unique characteristics of small grain sizes achieved through rigid thermo-mechanical treatments and very low content of specific alloying elements. However, some weldability problems have been identified and, thus, there is a need for studying their behavior under welding thermal cycles.

One of the most important aspects of steel weldability is the metallurgical features (grain size and microstructure) of the coarse grain (CG) region in the heat affected zone (HAZ). HAZ hardenability is an intrinsically dependent on the steel composition (in general, the higher the alloying element contents, the harder and more brittle the steel is after cooling) 
and grain size (the coarser the austenite grains, the higher the hardenability). HAZ toughness, in turn, is dependent of the hardenability and precipitations/microphases formation. The resultant effect of this complex relationship is governed by the thermal cycle imposed by the welding process in the coarsened grain HAZ (CGHAZ) in HSLA steels.

A feasible and user-friendly way to study some aspects of the steel weldability related to the CGHAZ is through the CCT diagrams. From these, it can be determined the range of cooling rates from the peak temperature achieved in the CGHAZ that can lead to desirable microstructures and hardness (preferably resistant and tough microconstituents). These diagrams are generated using techniques (usually refereed as physical or thermal simulations) that impose different weld thermal cycles on specimens and procedures to detect the starting and finishing transformation temperatures during cooling. Finally, it is performed a characterization of the microstructure and hardness at room temperature.

There are different methods for simulating weld thermal cycles and to measure the phase transformation temperatures. Mandziej (2010) shows in his paper several examples of simulation procedures and their physical backgrounds are discussed. Each method has its own characteristics, advantages and disadvantages. For instance, Adonyi (2006) provides an overview and discussion on the advantages and disadvantages of physical simulations from a user perspective, as applied to weld heat-affected zone (HAZ) characterization, including some warnings about improper use of the Gleeble, one of the most popular means of simulations. In summary, a common characteristic of all the methods is the low runtime and resource consumption (besides equipment costs) and the higher accuracy in determining the cooling rates when compared to real weldments, for the same purpose.

However, they have two major limitations: do not allow determining mechanical properties, other than hardness, due to the small size of the specimens; do not account for the constringing effect on austenite grain growth due to the thermal gradient observed in real welds. According to Alexandrov and Lippold (2004), some thermo-mechanical simulators may not be capable of reproducing the extremely high heating and/or cooling rates at the high temperature range, that are typical for the most welding processes. This results in longer dwell times in austenite phase field (for steels), leading to larger grain size, lower transformation temperatures and consequently higher content of lower temperature products of austenite decompositions and higher hardness in the simulation specimens, compared to the real HAZ. On the other hand, Miranda \& Fortes (1889) found that the grain sizes measured both in a simulation by dilatometer and in a real weld are comparable.

Table 1 presents some examples of methods and parameters applied to do similar thermal simulations. Unfortunately, in several papers some key-parameters, such as heating times, are not provided by the authors. One can see that different authors used different test setting parameters. And no data on the influence of the key-parameters on the resultant microstructures was found in current literature.

In addition, there are some discrepancies in the terminology used for the CGHAZ microconstituents. Lane et al. (2012) found

Table 1. Examples of Methods and test parameters used by different research groups in thermal simulation of weld HAZ

\begin{tabular}{|c|c|c|c|c|}
\hline Simulation Method & Heating rate $\left({ }^{\circ} \mathrm{C} / \mathrm{s}\right)$ & Peak temperature $\left({ }^{\circ} \mathrm{C}\right)$ & Holding time (s) & Source \\
\hline Gleeble/Dilatometer & 500 & 1000 to 1350 & 1 & Bayraktar \& Kaplan (2004) \\
\hline Gleeble & 100 & 1300 & 1 & Caron et al. (2010) \\
\hline Dilatometer & 50 & 1350 & 5 & Kuzmikova et al. (2010) \\
\hline Gleeble & 500 & 1350 & 1 & Lane et al. (2012) \\
\hline Gleeble & Not provided & 1350 & 1 & Liou et al. (2002) \\
\hline Dilatometer & 30 & $1150-1250$ & Not provided & Loureiro \& Fernandes (1994) \\
\hline Dilatometer & 40 & 950 to 1250 & 30 & Miranda \& Fortes (1989) \\
\hline Dilatometer & 150 & 1200 & Not provided & Onsøien et al. (2009) \\
\hline Smitweld & 150 & 975 & 0.5 & Samardžić et al. (2013) \\
\hline Gleeble & 433 & 1300 & 2 & Shi \& Han (2008) \\
\hline Gleeble & 200 & 1000 to 1400 & 0.15 & Shome \& Mohanty (2006) \\
\hline Dilatometer & 100 & 1400 & Not provided & Spanos et al. (1995) \\
\hline Gleeble & 400 & 1350 & 0.5 & Zheng et al. (2010) \\
\hline
\end{tabular}

Table 2. Groups of laboratories and correspondent activities in the Round-Robin Test trial

\begin{tabular}{|l|l|l|l|l|}
\hline Laboratory Groups & \multicolumn{1}{|c|}{ I } & \multicolumn{1}{|c|}{ II } & \multicolumn{1}{|c|}{ III } & \multicolumn{1}{|c|}{ IV } \\
\hline Thermal simulations & Lab A & Lab B & Lab C & Lab D \\
\hline Microstructural and hardness characterizations & Lab K and Lab P & Lab L & Lab N & Lab M \\
\hline
\end{tabular}


as resulting microstructure in the HAZ of a microalloyed steel, corresponding to a $\Delta \mathrm{t} 8-5$ equal to approximately 30 seconds, a mixture of grain boundary ferrite (GBF), Widmanstätten ferrite (WF), acicular ferrite (AF) and upper bainite (UB) phase. For other steels, the microstructure consisted, according to them, of bainitic ferrite with aligned second phase. Ferritic laths of upper bainite was observed by Kuzmikova et al. (2010) in the microstructure formed during $5^{\circ} \mathrm{C} / \mathrm{s}$ cooling, formation of which is strongly suppressed in favor of a lower bainite-martensite mixture with increasing cooling rate. Shome and Mohanty (2006) mentioned that acicular ferrite (AF) and lath martensite (LM) phases are formed in thermal simulations of coarse-grain heat-affected zones of HSLA-80 and HSLA-100 steels. In an attempt to describe all possible ferrite morphologies formed by decomposition of austenite in modern microalloyed steels, apart from matensite, the Iron and Steel Institute of Japan (ISIJ) recognized five separate forms of ferrite, i.e., polygonal ferrite, widmanstäten ferrite, quasipolygonal ferrite, granular ferrite, and bainitic ferrite, as described by Krauss and Thompson (1995). Cruz-Crespo et al. (2013) state that microconstituent nomenclature for carbon steel HAZ is still not harmonized, so they adopted the nomenclature from the Atlas for Bainitic Microstructures, developed by the ISIJ. As seen, the microconstituent terminology is not universally adopted by different researchers for potentially similar microstructures.

Thus, despite of the importance of thermal simulation in welding, but considering that, based on the literature, there are no standard procedures for conducting the tests and certify the accuracy of the methods with actual welds, and in addition, there is no harmonized terminology for HAZ constituents, the objective of this work was, through a round-robin test trial, to show the influence of different procedures and the characteristics of different methods on the drawing of a CCT diagram and to assess the degree of concordance between different researching groups on microconstituents nomenclature.

\section{Case study: An API X-70 Nb microalloyed steel used in lining piping}

The Round-Robin test trial was run in different countries; in four laboratories to perform the thermal cycle simulations

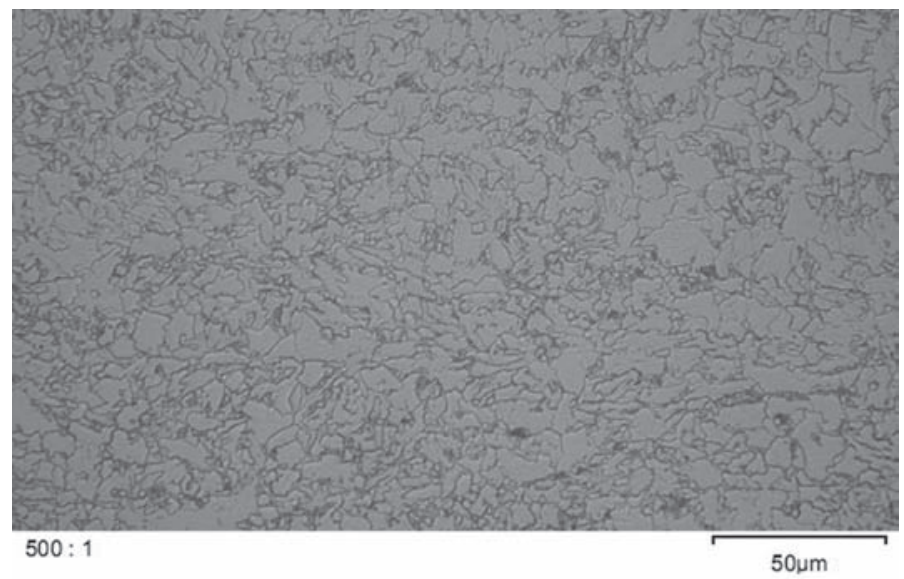

Figure 1. Microstructure of the API X-70 Nb microalloyed steel used in the Round-Robin test trial and in five laboratories to characterize the specimens, both the microstructure and hardness. They were randomly distributed in four groups, as shown in Table 2. Samples from the same material were machined as specified by each lab and sent to the 4 labs for the simulations. Each lab forwarded the samples after simulation to a correspondent laboratory for hardness and microstructural characterizations.

The chosen material for the simulations was an API class X-70 ( $\mathrm{Nb}$ microalloyed steel) used in piping. Figure 1 shows that the base material is a hot rolled condition with fine polygonal ferrite and pearlite. Tables 3 and 4 present the chemical composition and the mechanical properties of the steel under study.

Table 3. Chemical composition (wt. \%) of the API X-70 Nb microalloyed steel $\left(\mathrm{CE}_{\text {IIW }}=0.34\right)$

\begin{tabular}{|c|c|c|c|c|c|c|c|}
\hline $\mathrm{C}$ & $\mathrm{S}$ & $\mathrm{N}$ & $\mathrm{Al}$ & $\mathrm{Si}$ & $\mathrm{P}$ & $\mathrm{Ti}$ & $\mathrm{V}$ \\
\hline 0.04 & 0.001 & 0.0048 & 0.03 & 0.29 & 0.013 & 0.013 & 0.003 \\
\hline $\mathrm{Cr}$ & $\mathrm{Mn}$ & $\mathrm{Ni}$ & $\mathrm{Cu}$ & $\mathrm{Nb}$ & $\mathrm{Mo}$ & $\mathrm{B}$ & \multirow{2}{*}{} \\
\cline { 1 - 7 } 0.04 & 1.54 & 0.253 & 0.238 & 0.037 & 0.014 & 0.0003 & \multicolumn{1}{|c}{} \\
\cline { 1 - 5 } & &
\end{tabular}

Table 4. Mechanical Properties of the API X-70 Nb microalloyed steel

\begin{tabular}{|c|c|c|c|c|}
\hline $\begin{array}{c}\text { Yield } \\
\text { Strength } \\
\text { (MPa) }\end{array}$ & $\begin{array}{c}\text { Tensile } \\
\text { Strength } \\
\mathbf{( M P a )}\end{array}$ & $\begin{array}{c}\text { Strain } \\
\mathbf{( \% )}\end{array}$ & $\begin{array}{c}\text { Hardness } \\
\left.\mathbf{( H V}_{\mathbf{1 0} \mathbf{~ k g}}\right)\end{array}$ & $\begin{array}{c}\text { Absorbed } \\
\text { Energy } \\
\text { [Charpy] at } \\
\mathbf{- 8 0}^{\circ} \mathbf{C} \text { (J) }\end{array}$ \\
\hline $529 \pm 11$ & $620 \pm 7$ & $50 \pm 2$ & $181 \pm 7$ & $501 \pm 4$ \\
\hline
\end{tabular}

Each laboratory responsible for the simulations was oriented to simulate about 10 to 15 different thermal cycles with the following parameter restrictions:

- peak temperature: $1350{ }^{\circ} \mathrm{C}$;

- heating time: up to $5 \mathrm{~s}$;

- holding time: up to $2 \mathrm{~s}$;

- no mechanical pressure was applied on the samples;

- cooling rates between 800 and $500{ }^{\circ} \mathrm{C}\left(\Phi_{8-5}\right): 2$ to $130{ }^{\circ} \mathrm{C} / \mathrm{s}$

Table 5 summarizes the heating method and the settings used in each laboratory. Three different heating methods were used. In the first method (Joule heating), heating is reached by making a high AC current pass through the samples. Different heating and cooling times were reached through calculated variations of the sample geometry (Figure 2(a)), with no control imposed on the flowing current, except turn off the power when the desired temperature was reached (Vilarinho and Araujo, 2010). Figure 3 presents typical thermal cycle curves produced by Lab A. The second method uses a commercial Gleeble System which also use heating by the Joule Effect, yet a control of current flow is imposed for reaching the desired heating and cooling rates (samples are shown in Figure 2(b)). Finally, high-speed dilatometers were used as a third method with an inductive coil furnace to heat the samples (Figure 2(c)) and provide a controlled cooling environment. Figure 4 depicts a typical thermal cycle curve produced in Laboratory $\mathrm{C}$ dilatometer. 
Table 5. Simulations settings used in different Labs to carry out the thermal simulations

\begin{tabular}{|l|c|c|c|c|}
\hline & Lab A & Lab B & Lab C & Lab D \\
\hline Method of Simulation & Heating by Joule effect & Dilatometer & Dilatometer & Gleeble \\
\hline Peak temperature $\left({ }^{\circ} \mathbf{C}\right)$ & 1350 & 1350 & 1350 & 1350 \\
\hline Heating time (s) & $\begin{array}{c}0.9 \mathrm{~s}\left(1290^{\circ} \mathrm{C} / \mathrm{s}\right) \text { for the fastest cooling } \\
\text { rate, progressively increasing up to } 23.6 \\
\mathrm{~s}\left(52.4^{\circ} \mathrm{C} / \mathrm{s}\right) \text { for the slowest one }\end{array}$ & $11.25 \mathrm{~s}\left(120^{\circ} \mathrm{C} / \mathrm{s}\right)$ & $5 \mathrm{~s}\left(270{ }^{\circ} \mathrm{C} / \mathrm{s}\right)$ & Not provided \\
\hline Holding time (s) & Null & Null & 2 & Not provided \\
\hline $\begin{array}{l}\text { Cooling rates } \mathbf{8 0 0}-500 \\
{ }^{\circ} \mathbf{C ~}\left({ }^{\circ} \mathbf{C} / \mathbf{s}\right)\end{array}$ & From 3.2 to 419 & From 2 to 130 & From 1 to 400 & From 2 to 130 \\
\hline
\end{tabular}

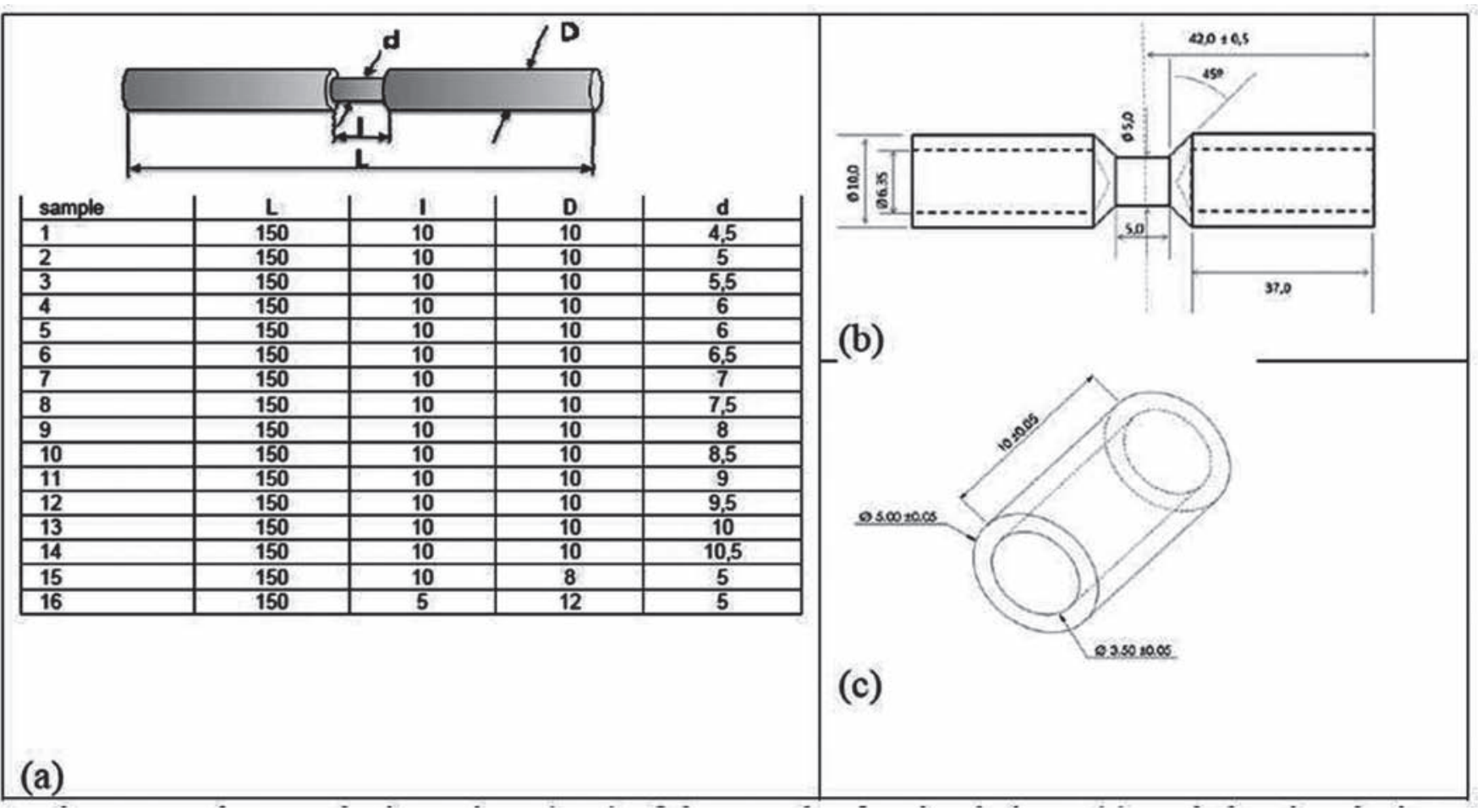

Figure 2. Geometry and dimensions (mm) of the samples for simulations heated: (a) by Joule effect; (b) in a Gleeble; (c) in a dilatometer

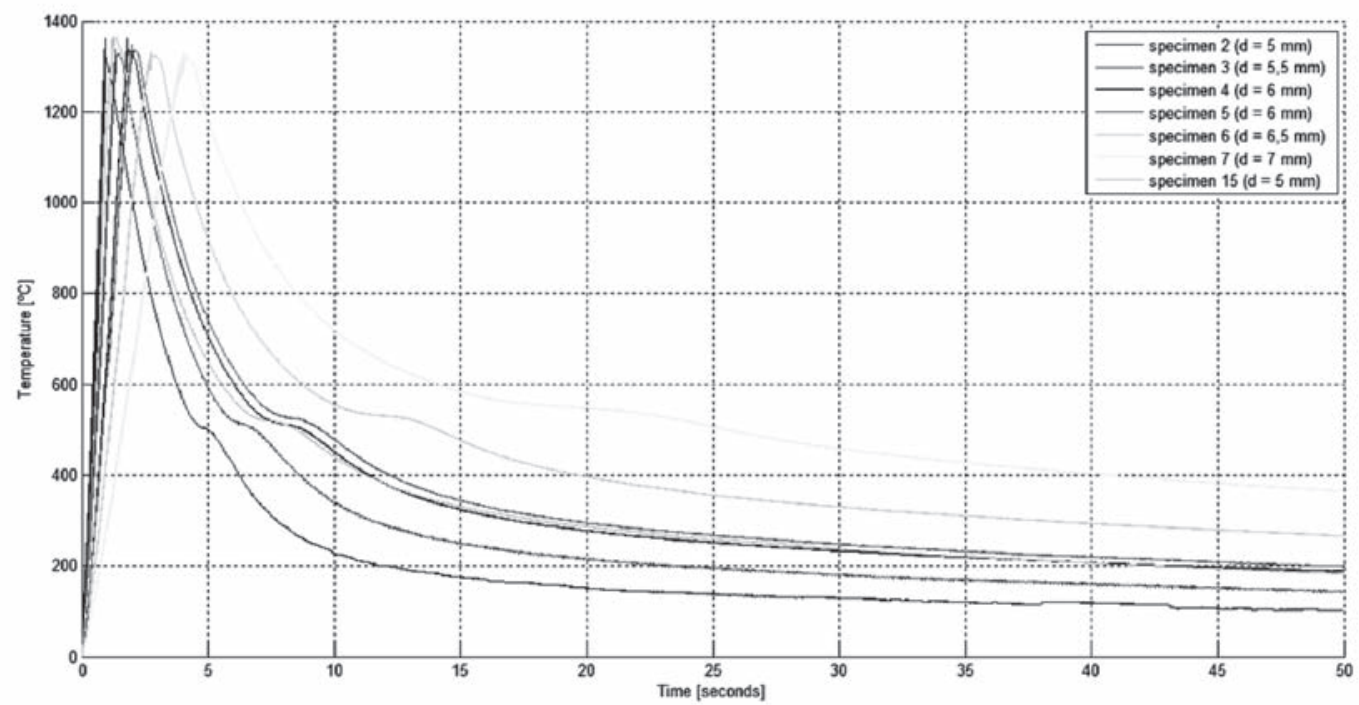

Figure 3. Thermal cycle curves produced by Lab A using an equipment based on heating by Joule effect 


\subsection{Microstructure Characterization}

After the simulations, the samples were transversally cut, polished and etched for optical metallography and microhardness measurements. Figure 5 illustrates the resulting microstructures, while Table 6 presents the microstructures identification per laboratory. As observed, there are no significant differences in the microstructures obtained after the same cooling rates in the different laboratories or using different methods of simulation. However, Table 6 shows that different labs use different terminology for, apparently, the same constituents.

\begin{tabular}{|c|c|c|c|c|}
\hline $\mathbf{N r}$ & Name & $\mathbf{t 8 . 5}$ & ${ }^{\circ} \mathrm{C} / \mathrm{s}$ & solid/hollow \\
\hline 1 & $\mathrm{q}$ & 0.75 & 400 & Hollow \\
\hline
\end{tabular}

\section{Dilatometer curve:}

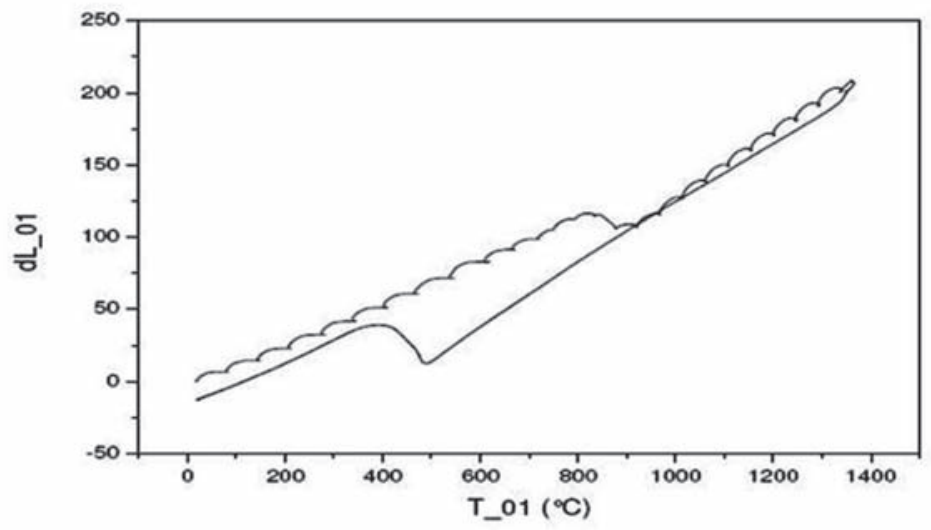

\begin{tabular}{|l|l|}
\hline$A_{c 1}$ & $829^{\circ} \mathrm{C}$ \\
\hline$A_{c 3}$ & $897^{\circ} \mathrm{C}$ \\
\hline$T_{s}$ & $490^{\circ} \mathrm{C}$ \\
\hline$T_{f}$ & $403^{\circ} \mathrm{C}$ \\
\hline
\end{tabular}

Figure 4. A typical thermal cycle curve produced in a hollow specimen by a high speed dilatometer

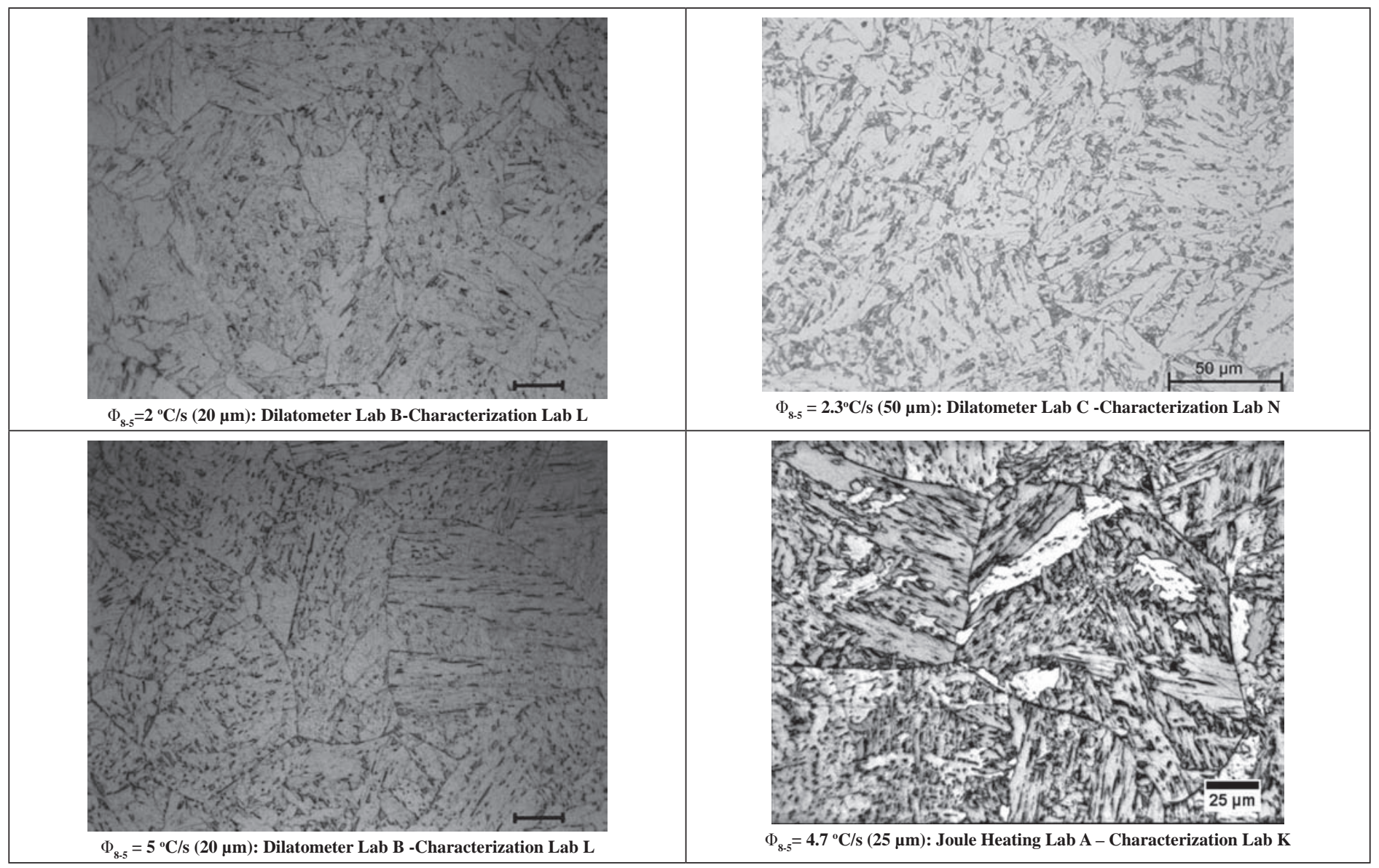




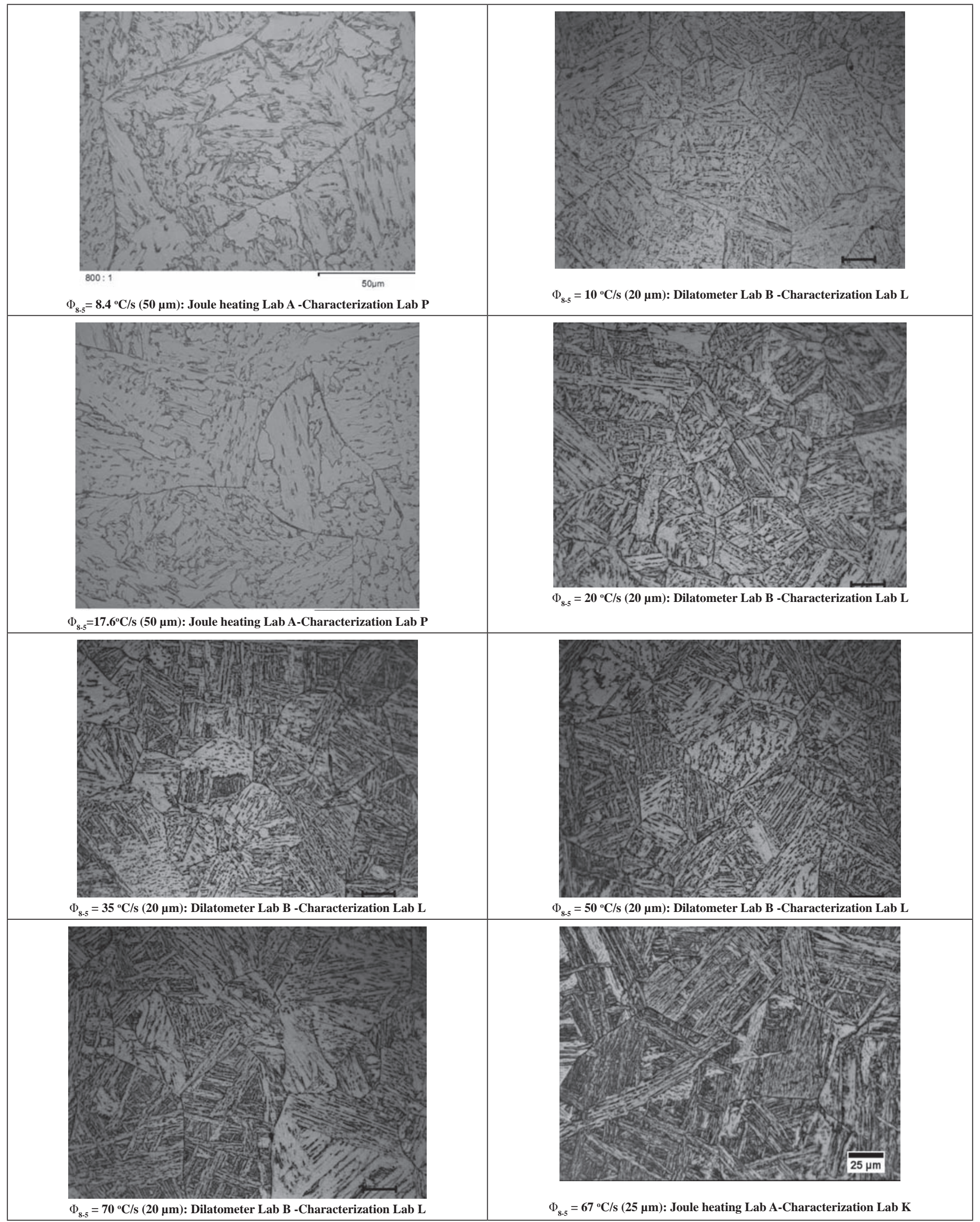




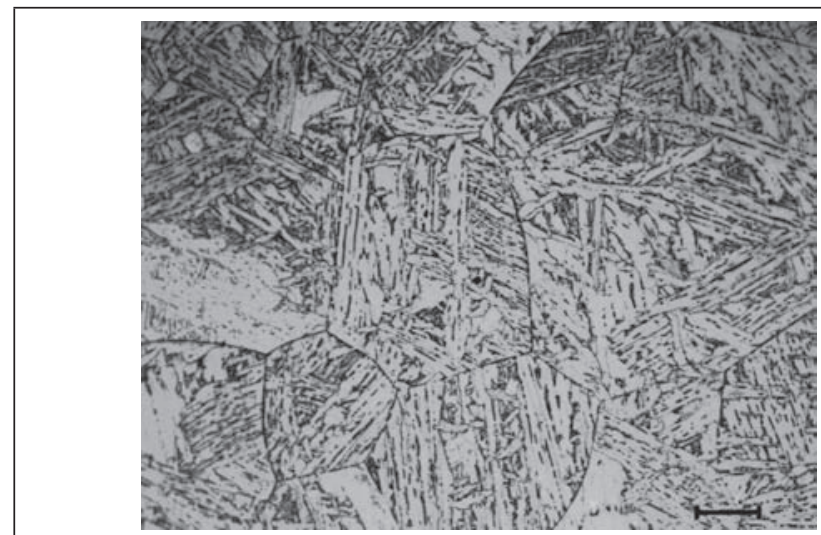

$\Phi_{8.5}=90^{\circ} \mathrm{C} / \mathrm{s}(20 \mu \mathrm{m}):$ Dilatometer Lab B-Characterization Lab L

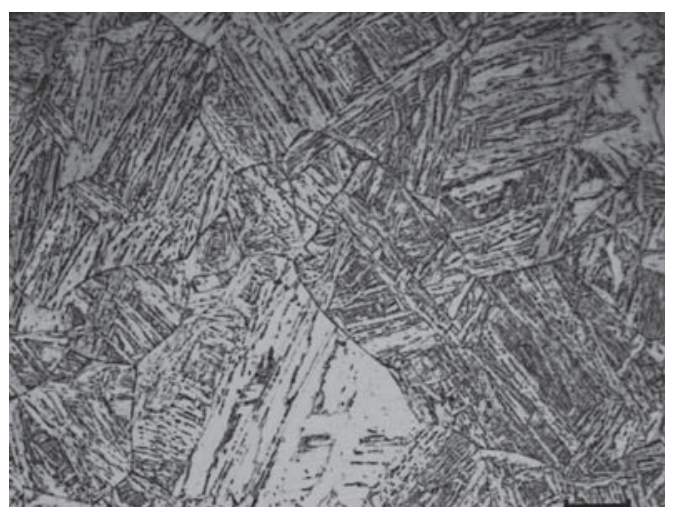

$\Phi_{8.5}=110{ }^{\circ} \mathrm{C} / \mathrm{s}(20 \mu \mathrm{m})$ : Dilatometer Lab B-Characterization Lab L

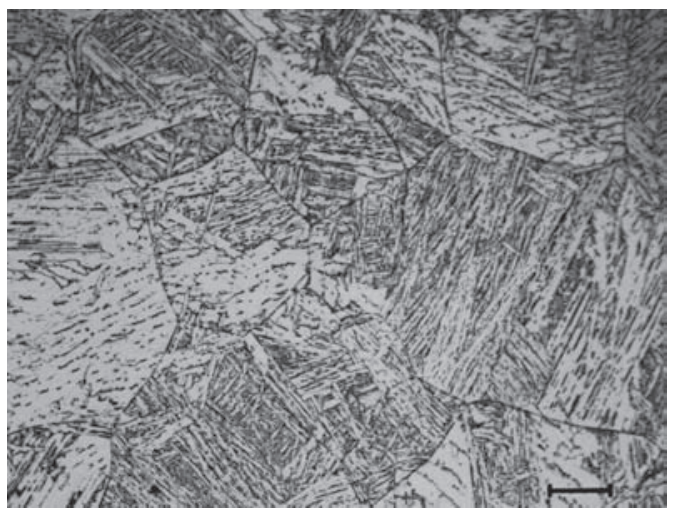

$\Phi_{8.5}=130{ }^{\circ} \mathrm{C} / \mathrm{s}(20 \mu \mathrm{m})$ : Dilatometer Lab B-Characterization Lab L

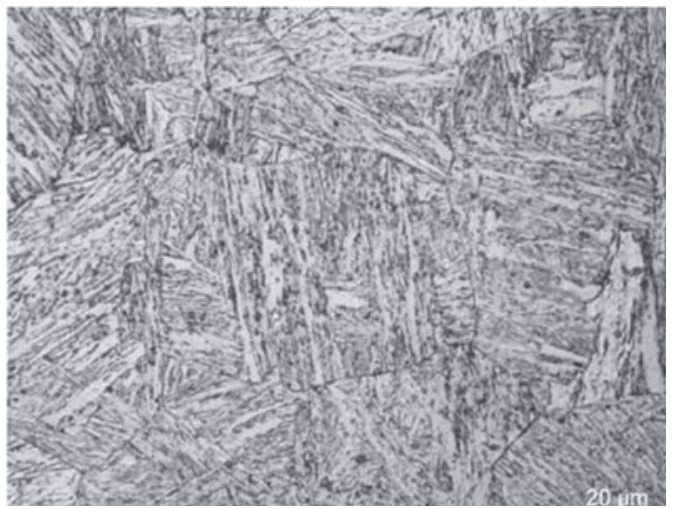

$\Phi_{8.5}=400{ }^{\circ} \mathrm{C} / \mathrm{s}(20 \mu \mathrm{m})$ : Dilatometer Lab C-Characterization Lab N

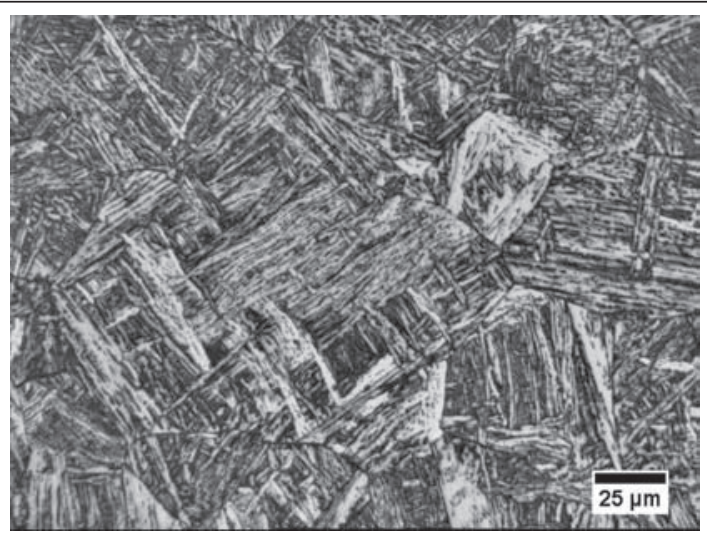

$\Phi_{8.5}=92^{\circ} \mathrm{C} / \mathrm{s}(25 \mu \mathrm{m})$ : Joule heating Lab A-Characterization Lab K

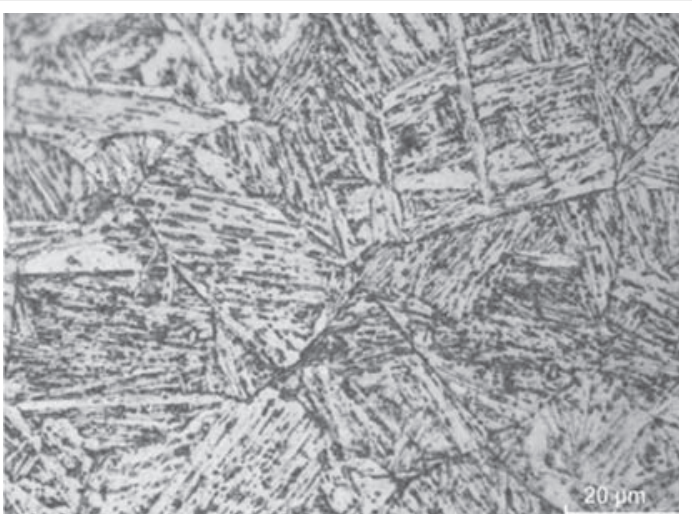

$\Phi_{8.5}=110^{\circ} \mathrm{C} / \mathrm{s}(20 \mu \mathrm{m})$ : Dilatometer Lab C-Characterization Lab N

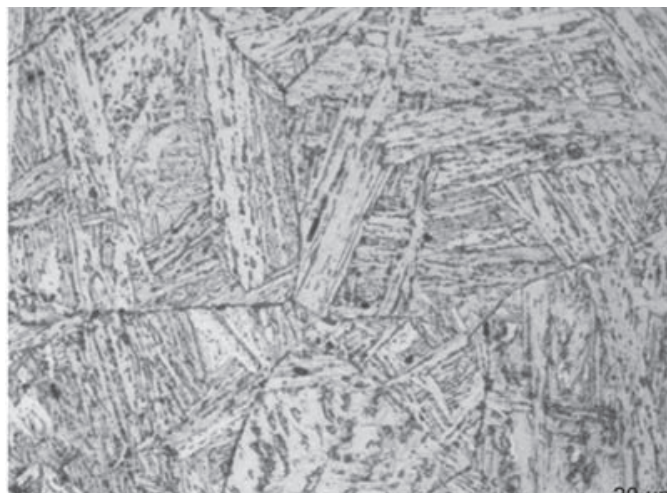

$\Phi_{8.5}=130^{\circ} \mathrm{C} / \mathrm{s}(20 \mu \mathrm{m})$ : Dilatometer Lab C-Characterization Lab N

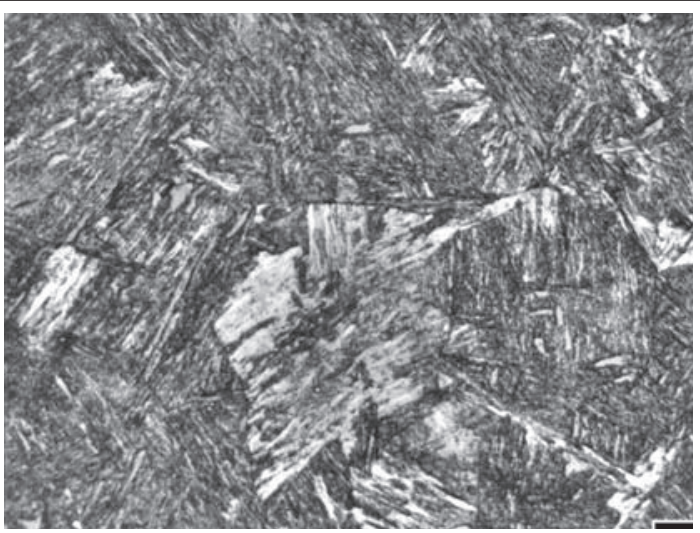

$\Phi_{8.5}=419{ }^{\circ} \mathrm{C} / \mathrm{s}(25 \mu \mathrm{m})$ : Joule Heating Lab A-Characterization Lab K

Figure 5. Microstructures from different cooling rates between 800 and $500{ }^{\circ} \mathrm{C}$, using distinct thermal cycle simulation methods 


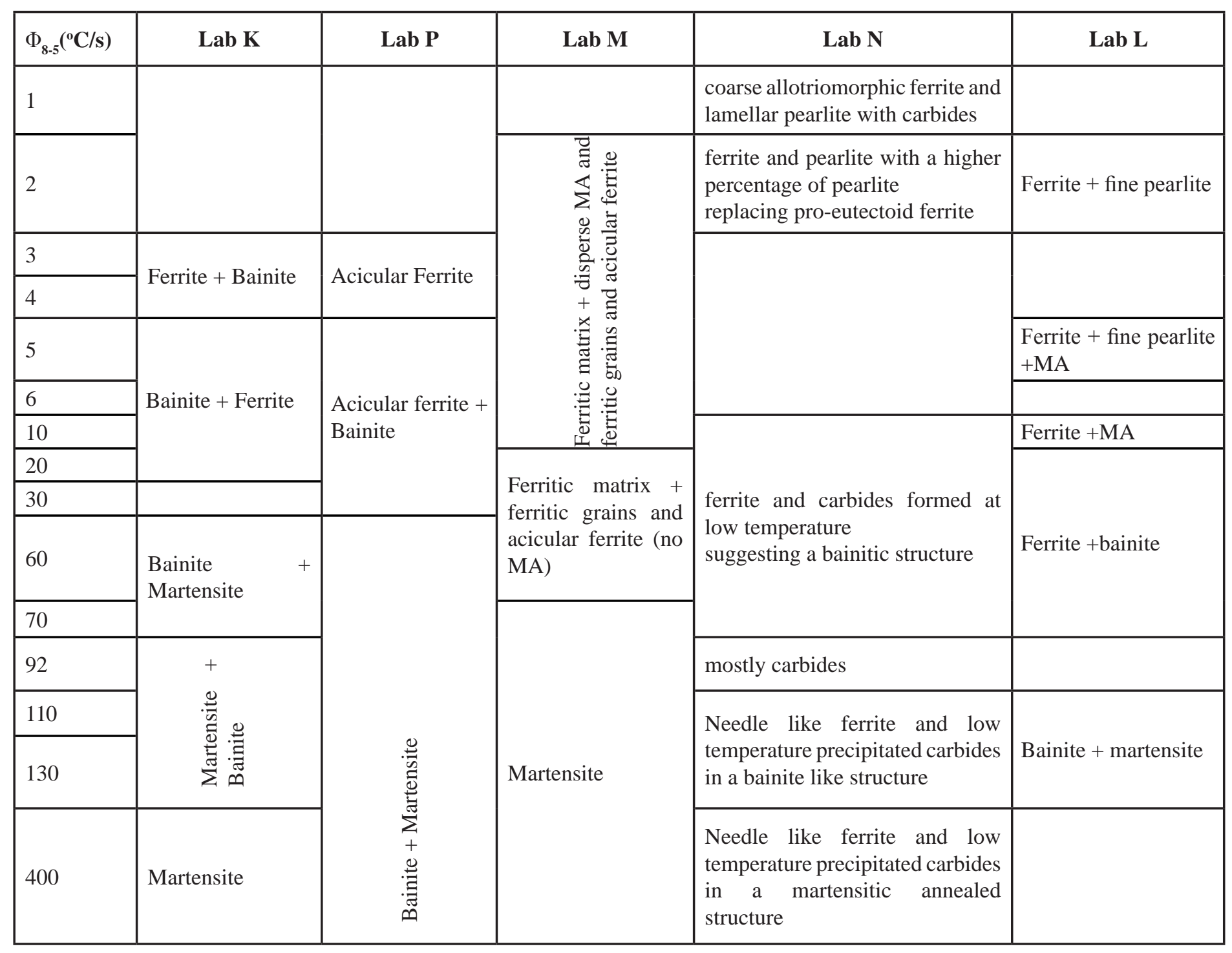

Table 6. Identification of the microstructures as a function of the cooling time between 800 and $500{ }^{\circ} \mathrm{C}\left(\Phi_{8-5}\right)$ in each Laboratory

Figure 6 presents the micro-hardness Vickers results from the different samples. A first observation is that each laboratory used different indentation loads. It can be seen that, except Lab $\mathrm{M}$, the others are consistent, though hardness values measured in Lab $\mathrm{K}$ are slightly lower and the ones from Lab $\mathrm{L}$ are higher. These correspond to different simulation methods and indentation loads. The likely reason for the results of Lab M is a lack of calibration in the cooling rates, as evidenced by the microstructures depicted in Figure 7.

As far as phase transformation temperatures are concerned (Figure 8), the dispersion of data is between 50 and $100{ }^{\circ} \mathrm{C}$, for the slower and the faster cooling rates, respectively. This can be acceptable, considering that there are no standard procedures to determine the transformation temperatures. The method to determine the starting and finishing points of the transformations when heating by Joule effect was a differential analysis, as described by Zachrisson (2006). This consists on performing a regression analysis on a section of the experimental cooling curve, assuming that the curve that best fits the experimental one is exponential with an equation of the type $T_{\text {reg }}=a e^{b t}+c e^{d t}$, where $\mathrm{a}, \mathrm{b}, \mathrm{c}$ and $\mathrm{d}$ are coefficients obtained by regression analysis and $t$ is the time, and then extrapolate this to temperatures below transformation. The difference between the experimental curve $(\mathrm{T}=\mathrm{f}(\mathrm{t}))$ and the regression curve in the region where deviation is perceived $\left(\mathrm{D}(\mathrm{T})_{\mathrm{i}}=\mathrm{T}_{\mathrm{i}}-\mathrm{T}_{\text {regi }}\right.$ ) is plotted as a function of temperature, thereby obtaining the temperatures of the transformations.

The method used in dilatometer is based on plotting the differential linear variation ( $\mathrm{dl} / \mathrm{l})$ as a function of cooling time in $\mathrm{s}$. The linear part of the curve is identified and a tangent parallel to it is drawn beyond the point when the curves start to arc, below and above the start and finish of the transformation regime respectively. The transformation start and finish temperatures are determined where the curves started to deviate from linearity. 


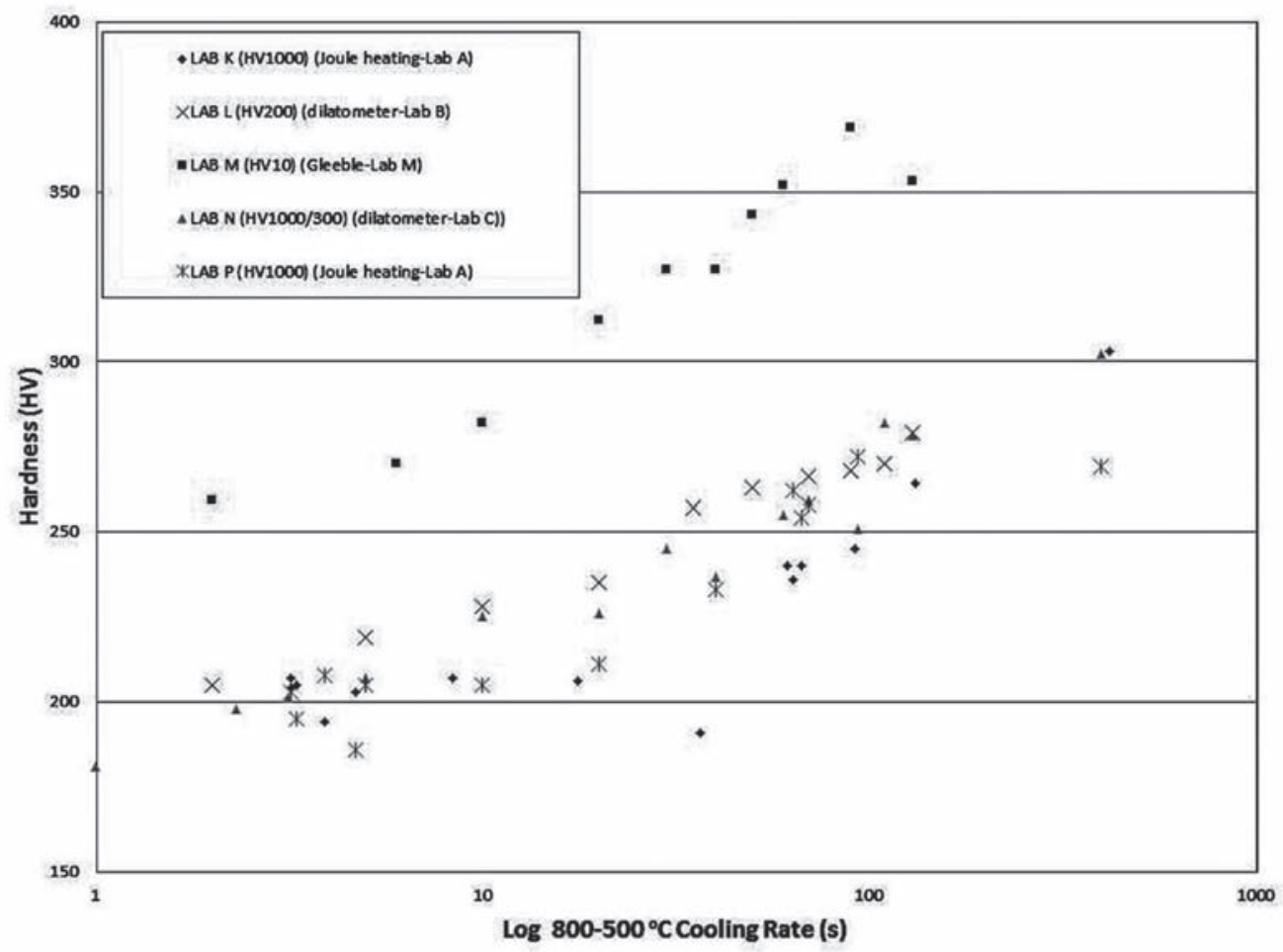

Figure 6. Average micro-hardness as a function of the cooling time between 800 and $500{ }^{\circ} \mathrm{C}$, using different thermal cycle simulation methods (Lab K: Joule effect; Lab L: Dilatometer; Lab M: Gleeble; Lab N: Dilatometer)

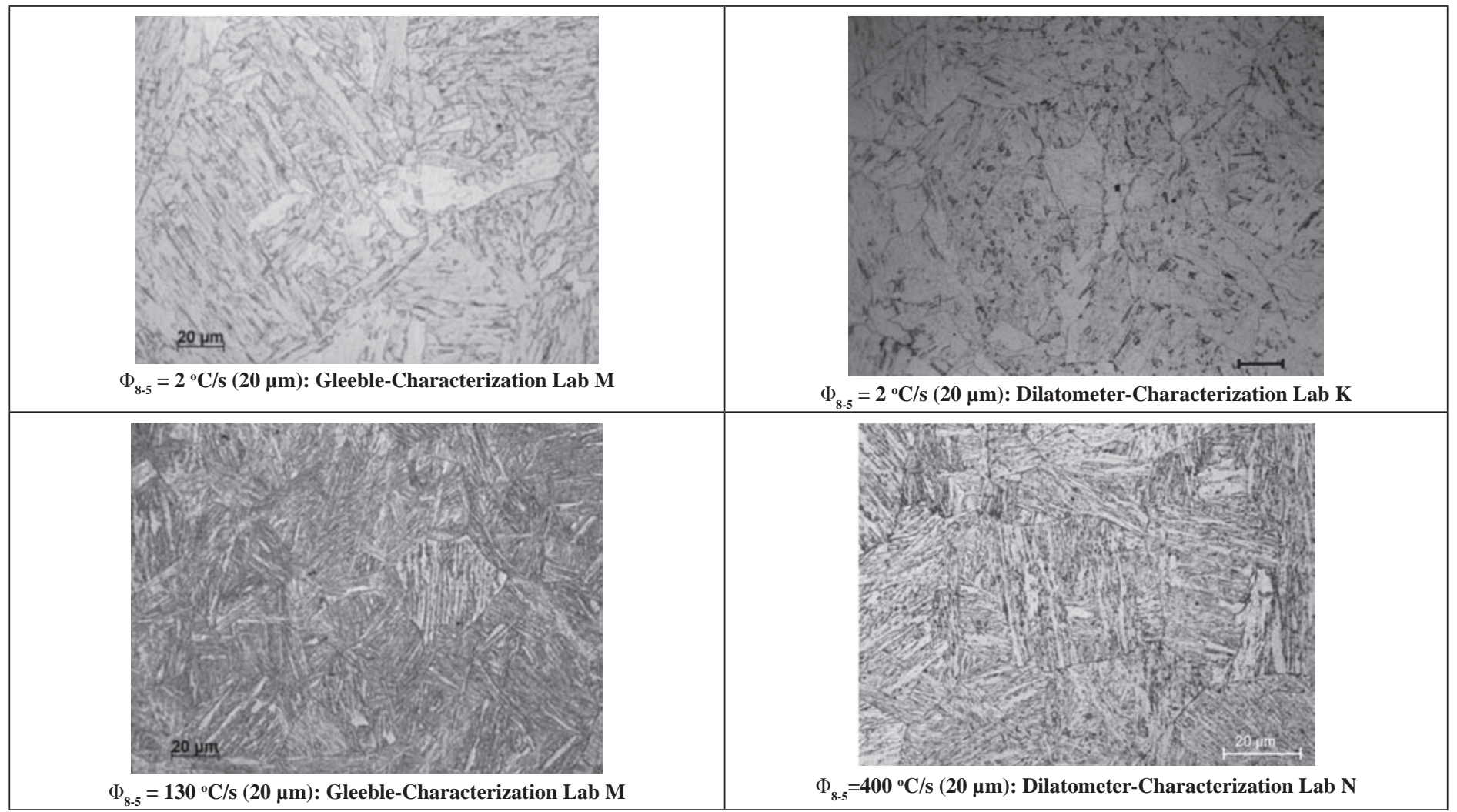

Figure 7. Comparison of microstructures obtained from simulations in Gleeble and Dilatometer evidencing lack of calibration in the cooling rate: upper micrographs show dissimilar microstructures for the same nominal cooling rate; lower ones evidence similar microstructures for different nominal cooling rates 

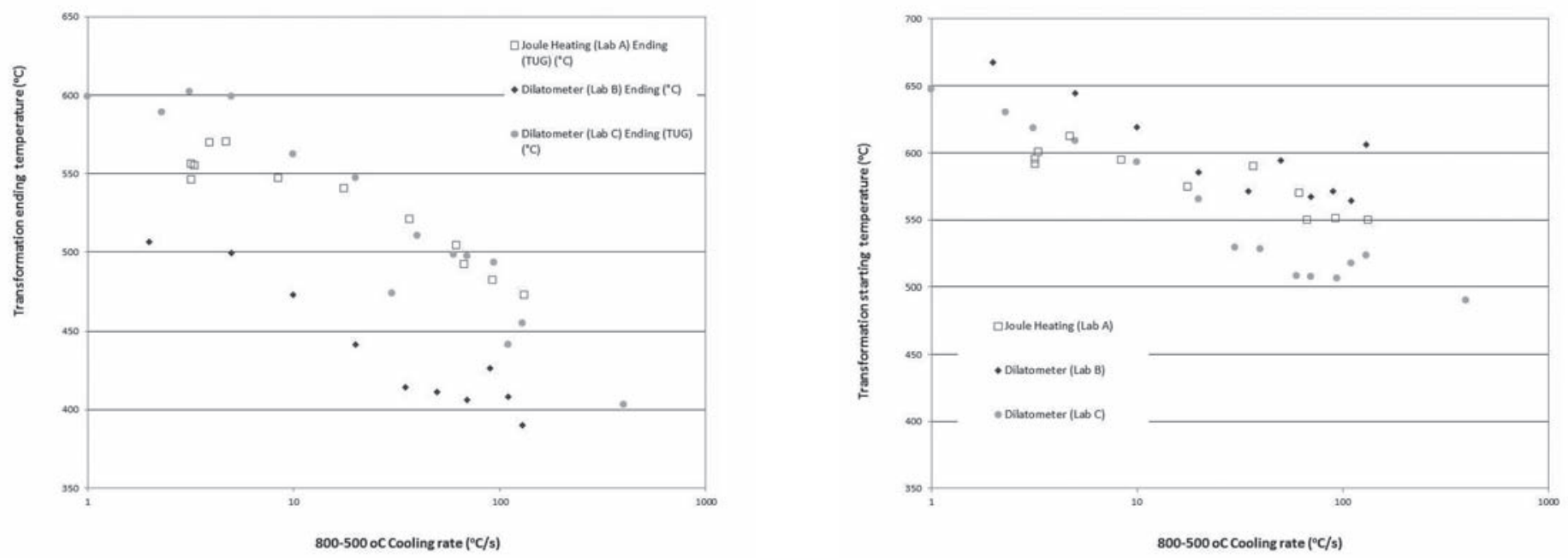

Figure 8. Starting and finishing transformation temperatures obtained for different simulation methods

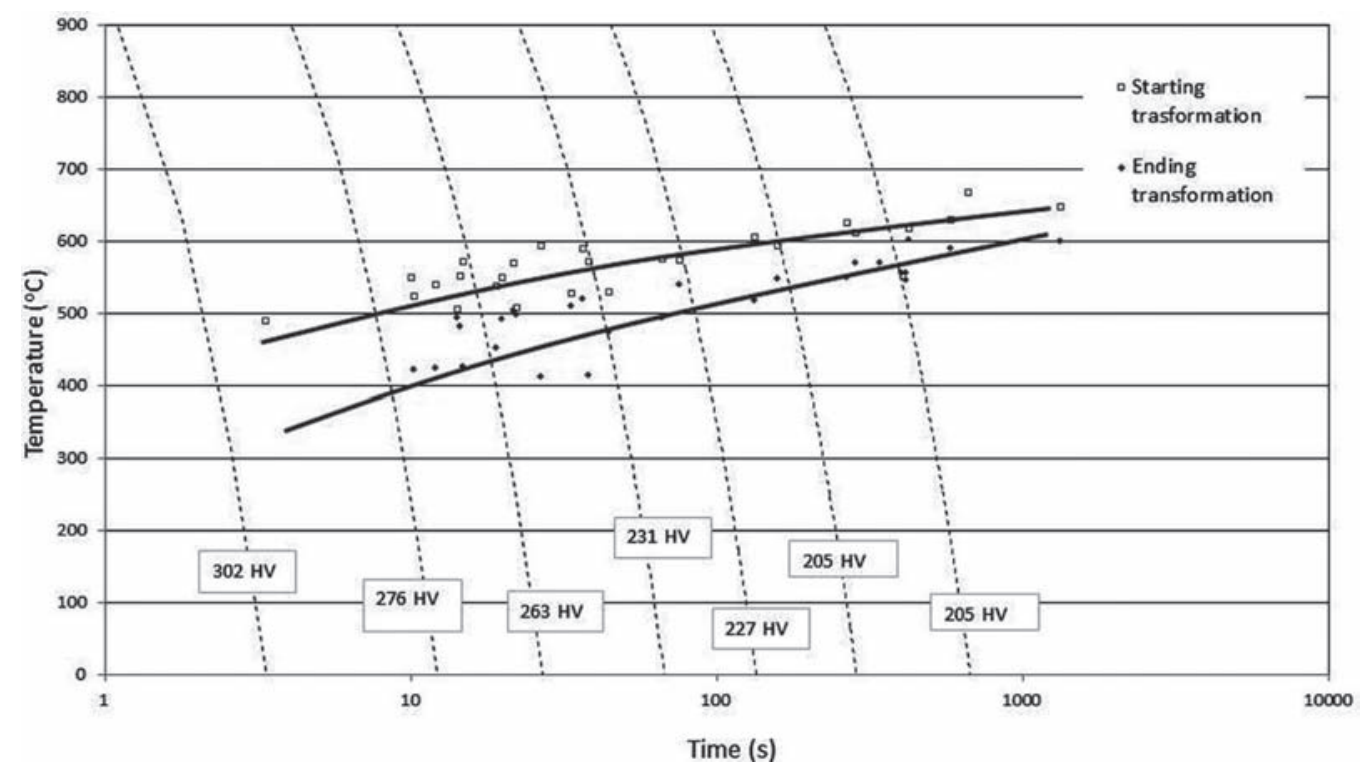

Figure 9. CCT diagram resulting from the Round-Robin test trial for the API X-70 Nb microalloyed steel

With the determined transformation temperatures, a CCT diagram was drawn for the given steel, as depicted in Figure 9. The transformation from austenite to bainite was predominant in the whole diagram range. These results are consistent with those reported by Zhang et al. (2009), Gorni \& Mei (2004) and Ivanov et al. (2011), who obtained CCT diagrams for steels with a similar composition as the one studied. The presence of martensite and bainite when applying high cooling rates is confirmed by hardness values of about $300 \mathrm{HV}$. This is also consistent with that reported by the above mentioned authors. Ivanov et al. (2011) shown that martensitic transformation is possible when the cooling rate exceeds $50{ }^{\circ} \mathrm{C} / \mathrm{s}$, which is confirmed by this study.

Conversely, none of the simulation methods detected the transformation of austenite to ferrite together with austenite to bainite at low cooling rates, which obviously occurs with a higher level of diffusion. Data from Gorni \& Mei (2004) shows the ferrite transformation at low cooling rates, below $0.5^{\circ} \mathrm{C} / \mathrm{s}$.
Also Ivanov et al. (2011) agreed it is possible to exist a ferrite transformation at cooling rates above $50^{\circ} \mathrm{C} / \mathrm{s}$.

\subsection{Discussion on the Round-Robin test trial}

As shown in Table 4, there are some small differences amongst the thermal cycle simulation methods and, in particular, the heating method. The Joule effect heating method incorporated much faster and variable heating rates (from 1290 to $52.4^{\circ} \mathrm{C} / \mathrm{s}$ ), while the dilatometer from Laboratories B and C kept the same values, yet different from each other, for the heating rate (120 ${ }^{\circ} \mathrm{C} / \mathrm{s}$ and $270{ }^{\circ} \mathrm{C} / \mathrm{s}$, respectively). Additionally, the holding time was set as null for the Lab A Joule Heating and the Lab B dilatometer methods and of $2 \mathrm{~s}$ for Lab C dilatometer method. In actual welds, null holding time and variable heating times are expected for different heat inputs, but the corresponding figures and the effect of these from a welding metallurgy perspective has not been available in current literature. 
In general, taking into account Figure 5, it can be said that the simulation method or the heat/holding time setting does not interfere in the final microstructures. However, looking at the resulting Vickers microhardness (Figure 6), excluding Lab M figures, it can be observed that the hardness measured in Lab $\mathrm{K}$ (using specimens simulated by Joule heating) is slightly lower than those measured in Lab L (using specimens simulated by dilatometer). This can be attributed to the differences in indentation loads or hardness tester calibration, but there is also an influence from the heating/holding time. This last assumption becomes more consistent if the transformation temperatures are observed in Figure 8. Lab B allowed for higher starting temperature and lower finishing temperature when compared to Lab C, with the same simulation method (dilatometer). The results of Lab A (Joule heating) are more similar to the ones from Lab C for the slower cooling rates and to Lab B for the faster cooling rates. This suggests that the differences are only of statistical deviations (simulation test and measurement robustness), but the implication of such differences is a scattered image when determining the CCT diagram (Figure 9).

In summary, this round-robin test trial allowed to evidence the need for further investigation in the application of welding thermal cycle simulations to draw CCT diagrams. Furthermore, more systematic trials could be implemented to study the robustness of each type of simulation. The influence of the heating and holding times on the resultant microstructure and corresponding hardness is an important issue. This is in agreement with Adonyi (2006) statement, that, in the absence of standards, mistakes in simulation can be made and incorrect conclusions can be drawn.

A comparison with real welds would allow to define the methods adequacy and test parameters. As a consequence, a procedure for performing simulations, including calibrations, could reduce data scattering and improve the accuracy of the CCT diagrams.

Another important point raised in this exploratory study is the need for standard nomenclature for HAZ microstructures. This has been successfully done in the past for weld metal through a "Guidelines for Classification of Ferritic Steel Weld Metal Microstructural Constituents Using the Light Microscope" (Pargeter and Dolby, 1985) but does not exist for the CGHAZ.

\section{Conclusions}

A round-robin test trial was conducted to assess the use of thermal cycle simulations for the characterization of the CGHAZ in a HSLA steel in order to build a Continuous Cooling Transformation diagram. Despite the exploratory character of this study, evidenced by the short number of laboratories involved, it was possible to show that this approach gives fair results, but with a reasonable degree of inaccuracy.

Even though the microstructures were not significantly different amongst the tested simulation approaches, differences were found in the transformation temperatures determined and in the hardness measurements. Scattering of results shows that further analysis needs to be implemented to verify the possibility of increasing the accuracy by means of standard procedures.
Finally, three major issues were identified:

a) The need for a international cooperative and multiinstitutional program to assess the effect of relevant simulation parameters, specially the heating rate and the holding time at peak temperature, on the final microstructure, transformation temperatures and hardness for a given cooling rate;

b) The need for calibration procedures for the simulation and measurement systems;

c) The need for the development of a common terminology of constituents in the heat affected zone (HAZ) of ferritic steels.

\section{Acknowledgements}

The authors would like to acknowledge and thank all the participants in the trial, the team which on a voluntary basis carried out the work, namely, Prof Huijun Li and Mr. Jai Ralph, from University of Wollongong, Australia, Dr. Antonio J. Ramirez and Ms. Thais Alonso, from the Brazilian National Nanotechnology Laboratory, Mr. Marcos Ponciano Souza and Mr. Luis C. Chad, from CONFAB, Brazil, Mr. Ledan Naves Oliveira Sobrinho, from the Center for Research and Development of Welding Processes, Federal University of Uberlandia, Brazil, Prof. Norbert Enzinger, from Graz University of Technology, Austria, Mr. Agustín Paz and Mr. Alberto Martinez, from Aimen (Association of Metallurgical Research of Northeast), Spain, Prof. Ivani de S. Bott, from Rio de Janeiro Pontifical Catholic University, Brazil, Prof. Rui Silva and Mr. Igor Santos, from New University of Lisbon, Portugal, and Prof. Noemí Mabel Ramini, from Technological National University, Argentina. They also would like to express their gratitude to the Brazilian councils for research development, CNPq (federal) and Fapemig (state), for the financial support.

\section{References}

- Adonyi, Y., 2006, Heat-Affected Zone Characterization by Physical Simulations: an overview on the use of the Gleeble discusses the advantages and disadvantages of thermomechanical simulation, Welding Journal, 85 (10), AWS, Oct 2006, pp. 42-47 (ISSN 0043-2296)

- Alexandrov, B.T., Lippold, J.C., 2004, Methodology for Insitu Investigation of Phase Transformations in Welded Joints, IIW Doc. IX-2114-04

- Bayraktar, E. \& Kaplan, D., 2004, Mechanical and metallurgical investigation of martensite-austenite constituents in simulated welding conditions, J. of Materials Processing Technology, 153-154 (2004), pp. 87-92 (doi:10.1016/j.jmatprotec.2004.04.021)

- Caron, J., Heinze, C., Schwenk, C., Rethmeier, M., Babu, S. S., Lippold, J., Effect of Continuous Cooling Transformation Variations on Numerical Calculation of Welding-Induced Residual Stresses, Welding Journal, AWS, 89 (7), Jul 2010, pp. 151s-160s

- Cruz-Crespo, A., Araujo, D.B., Scotti, A., 2013, Effect of Tempering Pass on HSLA-80 Steel HAZ Microstructures, Welding Journal, Oct 2013, 92 (10), pp. 304s-311s (ISSN 0043-2296) 
- Gorni, A. A., Mei, P. R. 2004. Austenite Transformation and Age Hardening of HSLA-80 and ULCB Steels. Journal of Materials Processing Technology, Vol.155-156, p.1513-1518 (doi:10.1016/j.jmatprotec.2004.04.245)

- Ivanov, A. Yu., Sulyagin, R. V., Orlov, V. V., Kruglova, A. A. 2011. Structure and Properties of Weld Joints inX80, X90, and K70 Pipe Steel. Steel in Translation, 41 (7), p. 611-616 (DOI: 10.3103/S0967091211070047).

- Krauss, G. and Thompson, S. W., 1995, Ferritic carbon microstructures in steels. ISIJ International, 35 (8), pp. 937945. Iron and Steel Institute of Japan Bainite Committee, 1992. Atlas for Bainitic Microstructures, Vol. 1, ISIJ, Tokyo, pp. 4-5

- Kuzmikova, L., Callaghan, M., Larkin, N., Scott, R., De Jong, R., Li, H., Norrish, J., 2010, A Study of the Continuous Cooling Behaviour and Effect of Preheat and Interpass Temperature on the HAZ of High Strength Quenched and Tempered Steel, IIW Doc. IX-2352-10, 14 p.

- Lane. N., Sterjovski, Z., Li, H., 2012, An Investigation of Simulated CGHAZ in HSLA65 and DH36 Naval Shipbuilding Steels, IIW Doc. IX-2417-12 (IX-L-1100-12), 19 p.

- Liou, H-Y., Hsieh R-I., Tsai, W-T., 2002, Microstructure and stress corrosion cracking in simulated heat-affected zones of duplex stainless steels, Corrosion Science, 44 (2002), pp. 2841-2856

- Loureiro, A.J.R. \& Fernandes, A.A., 1994, Toughness of CGHAZs of Welds in Q\&T Steels, Welding Journal, AWS, 84 (9), Sep 1994, pp. 225s-232s

- Mandziej, S. T., 2010, Physical Simulation of Metallurgical Processes, Materials and Technology, 44 (3), pp. 105-119, ISSN 1580-2949

- Miranda R. M. \& Fortes, M. A., 1989, Austenite grain growth, microstructure and hardness in the heat affected zone of a 2.25 Cr-1 Mo steel», Materials Science and Engineering: A, v. 108, Feb 1989, pp. 1-8. DOI: 10.1016/0921-5093(89)90399-7

- Onsøien, M.I., Hamdi, M.M’, Mo, A., 2009, A CCT Diagram for an Offshore Pipeline Steel of X70 Type, Welding Journal, AWS, 88 (1), Jan 2009, pp. 1s-6.s

- Pargeter, R.J., Dolby, R.E., Guidelines for Classification of Ferritic Steel Weld Metal Microstructural Constituents Using the Light Microscope, IIW Doc no. IX-1377-85, 1985

- Samardžić, I., Stoić, A., Kozak, D., Kladaric., I, Dunđer, M., 2013, Application of Weld Thermal Cycle Simulator in Manufacturing Engineering, Journal of Manufacturing and Industrial Engineering, 1-2(12), pp. 7-11, doi:10.12776/mie. v12i1-2.177

- Shi, Y., Han, Z., 2008, Effect of weld thermal cycle on microstructure and fracture toughness of simulated heataffected zone for a $800 \mathrm{MPa}$ grade high strength low alloy steel, J. of Materials Processing Technology, 207 (2008), pp. 30-39 (doi:10.1016/j.jmatprotec.2007.12.049)

- Shome, M., Mohanty, O.N., 2006, Continuous Cooling Transformation Diagrams Applicable to the Heat-Affected Zone of HSLA-80 and HSLA-100 Steels, Metallurgical and Materials Transactions A, v. 37A, Jul 2006, pp. 2159-2169

- Spanos, G., Fonda, R.W., Vandermeer, R.A., Matuszeski, A.,
1995, Microstructural Changes in HSLA-100 Steel Thermally Cycled to Simulate the Heat-Affected Zone during Welding, Metallurgical and Materials Transactions A, v. 26A, Dec 1995, pp. 3277-3293

- Vilarinho, L. O., Araújo, D. B.2010. Low-Cost Methodology for Obtaining CCT Welding Diagrams. Soldagem\& Insp., 15 (3), p. 184-190 (doi:10.1590/S0104-92242010000300004) (in Portuguese)

- Zachrisson, J. 2006. In Situ Detection and Characterization of Phase Transformations in Weld Metals. Master's Thesis. Master of Science Programme, Engineering Physics. Lulea University of Technology, p. 44.

- Zhang,Y. Q., Zhang, H. Q., Liu, W. M, Hou, H. 2009(a). Effects of $\mathrm{Nb}$ on Microstructure and Continuous Cooling Transformation of Coarse Grain Heat-Affected Zone in 610MPa Class High-Strength Low-Alloy Structural Steels. Materials Science and Engineering A, 499, p. 182-186.

- Zheng, H., Ye, X., Jiang, L., Wang, B., Liu, Z., Wang, G., 2010, Study on microstructure of low carbon $12 \%$ chromium stainless steel in high temperature heat-affected zone, Materials and Design, v. 31, pp. 4836-4841 